\title{
ZOOINWEKTYWY W RÓŻNYCH ODMIANACH JĘZYKA POLSKIEGO I UKRAIŃSKIEGO
}

\author{
HELENA SOJKA-MASZTALERZ \\ Uniwersytet Wrocławski, Wrocław - Polska \\ helena.sojka-masztalerz@uwr.edu.pl; ORCID 0000-0001-8225-2735 \\ ЗООІНВЕКТИВИ В РІЗНОВИДАХ
ПОЛЬСЬКОЇ ТА УКРӒ̈НСЬКОЇ̈ МОВ
}

Гелена Сойка-Машталеж

Вроцлавський університет, Вроцлав - Польша

\begin{abstract}
АНОТАЦІЯ. Апелятиви у функції зневажання вживалися вже у стародавні часи. Согодні виступають вони у стандартних та субстандартних різновидах даної мови (в загалнодержавнйі мові та в соціолектах). Метою статті є спроба показати, що дедалі частіше для вираження негативних емоцій стосовно адресата вживають інвективи утворені від назв тварин. В різновидах польської та української мов збільшується не тільки кількість зооінвектив, але відбувається також розширення семантики слів, первинне значення яких пов'язують із назвою тварини. Проаналізовані лексеми поділяються на дві групи: назви тварин, які мають кілька значень, але деякі з них перекриваютья (пол. baran - укр. баран, пол. cap - укр. изаn, пол. krowa - укр. корова), і назви, що мають абсолютно різні значення в обох мовах (пол. wydra- укр. видрa, пол. larwa - укр. лярва, пол. szakal - укр. шакал).
\end{abstract}

Ключові слова: соціолінгвістика, неосемантизація, зооінвектива, мовні контакти

\section{ANIMAL-RELATED INVECTIVES IN DIFFERENTS LANGUAGE VARIETIES OF POLISH AND UKRAINIAN}

\author{
HELENA SOJKA-MASZTALERZ
}

University of Wrocław, Wrocław - Poland 
ABSTRACT. Appelatives having an insulting function have been used since the earliest times. Nowadays, they are present in standard language and in substandard types of language (sociolects). The aim of the article is to show that animal-related invectives are more and more frequently used in order to express negative emotions towards the receiver. In Polish and Ukrainian, the number of animal-related invectives increases but also semantics of the words broaden as the meaning of those words originally referred to the name of a given animal. The lexemes were analyzed and divided into two groups: names of animals that have several meanings, but some of them overlap (pl. baran - ukr. баран, pl. сар - ukr. uan, pl. krowa - ukr. корова) and names that have completely different meanings in the two languages (pl. wydra - ukr. видра, pl. larwa-ukr. лярва, pl. szakal - ukr. шакал).

Keywords: sociolinguistics, neosematisation, animal-related invective, language contact

\section{Wprowadzenie: cel, metody, materiał źródłowy}

$\mathrm{W}$

śród wielu zagadnień, którymi zajmuje się współczesna socjolingwistyka, jest również problem charakteryzowania ludzi za pomocą nazw zwierząt ${ }^{1}$. Człowiek jako homo loquens - istota realizująca się poprzez mówienie opisuje i ocenia świat $\mathrm{z}$ antropocentrycznego punkt widzenia. W poczuciu dumy z własnej wartości ocenia niżej wszystko, co jest poza kręgiem ludzi [Skawiński 2002: 255; Peisert 2004: 86], a „dezaprobata zawarta w strukturze znaczeniowej metafor zwierzęcych jest pochodną prastarej motywowanej kulturowo i filozoficznie antynomii «człowiek : zwierzę»" [Sarnowski 1999: 92]. Stosowanie nazw zwierząt jako środka językowego mającego na celu obrażenie, ośmieszenie czy poniżenie drugiej osoby lub grupy osób znane jest od starożytności. Deprecjonujące określenia odzwierzęce występują zarówno w mowach Demostenesa, największego mówcy starożytnej Grecji, jak i w twórczości Franciszka Zabłockiego, najaktywniejszego satyryka Sejmu Czteroletniego, a także w XX-wiecznych wystąpieniach sejmowych [por. Kołodziejek 1994; Kamińska-Szmaj 2007]. Ekspresywne apelatywy występują coraz liczniej w środkach masowego przekazu, np. „Zrobiły to na własną rękę pieski telewizyjne, studyjne pinczery z ostrożności, ze strachu, żeby się nie narażać” [,Fakt”, 27.07.2009], czy w tytułach w tytułach artykułów w popularnych czasopismach) Mrówka cheerleaderka na robocie [,Gazeta Wyborcza”, 1.08.2020], Zwierzęta polityczne. Jak prawica się pogryzła [,Polityka”, 23-29.09.2020].

${ }^{1}$ Zagadnieniu inwektyw poświęciłam dwa wcześniejsze artykuły: O inwektywach zwierzęcych w języku polskim, [w:] Acta Universitatis Wratislaviensis. „Kształcenie Językowe”, Wrocław: Wydawnictwo Uniwersytetu Wrocławskiego, T. 8 (18), 2010, s. 11-24; Зооніми в соиіолекті девіаційних середовищ (спроба порівняння на польському та украйнському матеріалі), „Проблеми слов'янознавства”, Львів: Львівський націнальний університет імені Івана Франка, Випуск 61, 2012, c. 199-206. 
Przedmiotem rozważań uczynię zooinwektywy - wyrazy, które prymarnie stanowią nazwy ogólne i gatunkowe zwierząt, ale sekundarnie użyte w stosunku do człowieka pełnią funkcję obraźliwą, zniesławiającą, lekceważącą. W socjolektach dodatkowo pełnią one funkcję kodującą przekaz. Przeanalizuję neosemantyzmy oparte głównie na metaforyzacji, np. fląra 'kobieta niechlujna', глухар 'глуха людина', które mogą mieć strukturę wykrzyknienia wokatywnego, np. ty matpo! lub nominatywnego, np. корова!, i są bezpośrednio skierowane do odbiorcy albo określają go tak wobec osób trzecich ${ }^{2}$. Z gramatycznego punktu widzenia są to rzeczowniki występujące samodzielnie.

Inwektywy odzwierzęce występują zarówno w standardowej odmianie języka (czyli w języku ogólnym), jak i w substandardowych odmianach, m.in. w socjolektach ${ }^{3}$, np. w żargonie więziennym (czyli tajnej odmianie socjolektu). Praca stawia sobie za cel pokazanie, że coraz częściej do wyrażenia negatywnych emocji względem adresata używa się inwektyw odzwierzęcych w różnych odmianach języka polskiego i ukraińskiego, a świat zwierząt jest jednym z powiększających się pól semantyczno-leksykalnych polskiej oraz ukraińskiej leksyki znieważającej $^{4}$. Przedstawię przykłady świadczące o rosnącej liczbie określeń odzwierzęcych i o poszerzaniu się ich semantyki, zależnej m.in. od czynników etnicznych, kulturowych i środowiskowych.

Spośród całego słownictwa ekspresywnego, dotyczącego opozycji homo - animal analizie poddałam 142 jednostki polskie i 149 jednostek ukraińskich, zarejestrowanych w standardowej odmianie (w tym 98 ssaków, 21 ptaków, 14 owadów, 7 gadów, 2 płazy). Ze względu na występowanie w obu językach przedmiotem porównania uczyniłam jedną trzecią z nich (43 nazwom w języku polskim odpowiada 48 ukraińskich). Ponadto przeanalizowałam 162 jednostki polskie oraz 68 jednostek ukraińskich wynotowanych z obu socjolektów przestępczych. Przedmiotem

${ }^{2} \mathrm{~W}$ analizie pomijam pieszczotliwe zwroty kierowane do mężczyzny, np. лебidь lub do dziewczyny, kobiety - зозуля, чайка występujące w odmianie ogólnej. Nie omawiam także związków wyrazowych typu niebieski ptak w znaczeniu 'człowiek lekkomyślny, nieodpowiedzialny, niemający określonego zajęcia', cлiny курку - 'про людину, що погано бачить або короткозору', a także wokatywnych zdrobnień typu żabciu, kotku, tygryskи сонечко, зозулько, których konotacje czasami wynikają z szerszego kontekstu: intencji nadawcy, relacji między nadawca a odbiorcą.

${ }^{3} \mathrm{Za} \mathrm{S}$. Grabiasem socjolekty rozumiem jako „odmiany języka powstałe we wspólnotach ludzkich wyznaczonych pewnym rodzajem więzi społecznej” [Grabias 1994: 97]. Szerzej na ten temat pisze także Л. Ставицька w książce Арго, жаргон, сленг, Київ: Критика, 2005.

${ }^{4}$ Dowodem na poszerzające się pole agresji słownej wykorzystującej nazwy zwierząt w socjolekcie przestępczym jest porównanie indeksu nazw zwierząt, które podał H. Ułaszyn w pracy Język złodziejski [Łódź: Łódzkie Towarzystwo Naukowe 1951, 52-53] z danymi w Słowniku gwar środowisk dewiacyjnych K. Stępniaka. H. Ułaszyn odnotował tylko 29 takich nazw, K. Stępniak - 162. Również na materiale ukraińskim można zauważyć wzrost liczby tych nazw: Короткиŭ словник жаргонної лексии української мови [Ставицька 2003] odnotował 29 jednostek, z kolei Украӥнський жаргон. Словник [Ставицька 2005] о pięć przykładów więcej. 
porównania było 45 jednostek polskich i tyleż samo ukraińskich odpowiedników, które nie zawsze łączyło znaczenie, ale nazwa określonego zwierzęcia ${ }^{5}$. W pierwszej części omówię zooinwektywy występujące w odmianie ogólnej obu języków, w drugiej - zooinwektywy charakterystyczne dla socjolektu, a następnie wskażę wspólne cechy i różnice pomiędzy obydwoma odmianami. Tylko niektóre zooinwektywy, ze względu na ograniczone rozmiary artykułu, będą stanowiły przedmiot szczegółowej analizy.

Porównanie standardowej oraz substandardowej odmiany języka znajduje swoje uzasadnienie w materiale leksykalnym. Słowniki ogólne coraz częściej oprócz podstawowych i przenośnych znaczeń zamieszczają słownictwo nieoficjalne): potoczne, środowiskowe (żargon), np. pol. pies 'policjant' [SJPDun], suka 'samochód policyjny', [SJPDun, SJPDub], ukr. сука 'засуджений злодій, що злугався 3 керівництвом в'язниці й виконує його вкзівкі' [ВТСБ].

Podstawą materiałową są nazwy zwierząt wynotowane z trzech słowników ogólnych: Stownika języka polskiego pod red. M. Szymczaka [dalej jako SJPSz], Języka polskiego. Współczesnego stownika języka polskiego pod red. B. Dunaja [SJPDun], Uniwersalnego słownika języka polskiego pod red. S. Dubisza [SJPDub]. Wyekscerpowany materiał porównałam z zawartym w trzech ogólnych słownikach języka ukraińskiego. Są to: Великий тлумачний словник сучасної украӥнської мови, którego głównym redaktorem jest В.Т. Бусел [dalej jako ВТСБ], Новий тлумачний словник сучасної украӥнської мови: в трьох томах pod red. В. Яременка, О. Сліпушко [НТС], Словник української мови: в 11 тт. pod redakсја̨ I.К. Білодіда [СУМ]. Spośród kilku słowników specjalistycznych do analizy wybrałam dwa: Stownik gwar środowisk dewiacyjnych K. Stępniaka [dalej jako SGD] oraz Словник жаргону злчиниів, którego autorem jest O.I. Поповченко $[\mathrm{C} 3]^{6}$.

${ }^{5}$ Zestawiając ze sobą jednostki polskie i ukraińskie posługuję się neutralnym terminem odpowiednik. Uważam, że terminy synonim oraz wariant winny być używane wyłącznie dla jednostek jednego języka. Różnica w liczbie analizowanych nazw wynika ze stosowanych synonimów w danym języku, a nie z braku odpowiednika, np. pol. bydto - ukr. бидло//скотина, pol. bydlę-ukr. худоба// скотина, pol. gad - ukr. гад//плазун, pol. osiot - ukr. осел//вілсюк, pol. zwierze - ukr. звір//тварина, pol. żтіja - ukr. змія//гадюка, a także, np. ukr. теля-pol. cielę//cielak, ukr. курча-kurczę//kurczak. Znak // sygnalizuje, że jest to synonim występujący w danym języku. Z kolei znak / wskazuje na zapis nazwy zwierzęcia w języku polskim i jej ukraiński odpowiednik. W dalszej części pracy nazwy gatunkowe zwierząt nie będą poprzedzone skrótami: pol. na oznaczenie języka polskiego oraz ukr. na oznaczenie języka ukraińskiego.

${ }^{6}$ Nie wzięłam pod uwagę ważnego dla polskiej leksykografii socjolingwistycznej Słownika gwary studenckiej L. Kaczmarka, T. Skubalanki i S. Grabiasa, ponieważ zawiera on leksykę z lat 70. ubiegłego wieku. Słownik jest reprintem z 1974 roku. Nie odwołuję się także do Słownika polskich przekleństw i wulgaryzmów M. Grochowskiego oraz do Stownika eufemizmów polskich, czyli w rzeczy mocno, w sposobie łagodnie A. Dąbrowskiej ze względu na zbyt małą liczbę odnotowanych konstrukcji odpowiadających przedmiotowi) niniejszej analizy. 


\section{Hiperonimy w standardowej odmianie języka polskiego i ukraińskiego}

Ujemne nacechowanie mają nazwy ogólne: pol. zwierzę - ukr. звір//тварина, pol. bydto - ukr. бидло//скотина, pol. bydlę - ukr. худоба//скотина, pol. gad ukr. гад//плазун. I tak, SJPS i SJPDub podkreślają, że w języku potocznym ironicznie lub żartobliwie zwierzęciem można nazwać 'człowieka jako przedstawiciela najwyższego gatunku w klasyfikacji zoologicznej’, z kolei SJPDun zwraca uwagę, że można w taki sposób powiedzieć 'żartobliwie o człowieku lub pogardliwie o człowieku przejawiającym ujemne cechy charakteru'7. Użyte w przenośnym znaczeniu wyrazy звір lub тварина w języku ukraińskim mają zdecydowanie negatywną konotację i określone właściwości. Zooinwektywy звip używa się: ‘про дуже люту, жорстоку людину', wskazując jednoznacznie na konkretne cechy charakteru osoby. Z kolei тварина uznane zostało za obelżywe określenie: 'груба, підла людина'. Na takie same cechy wskazuje ukraińskie бидло oraz bliskoznaczne худоба, скотина. We wszystkich słownikach бидло definiowane jako ‘лайл. скотина, хам', худоба - 'те саме, що бидло', zaś скотина - 'про грубу, жорстоку, підлу людину" ${ }^{8}$. Niektóre z tych znaczeń pokrywają się z polskim odpowiednikiem bydle - to 'o kimś zachowującym się, postępującym w sposób niegodny człowieka' [SJPDun]. SJPSz oraz SJPDub doprecyzowują, wymieniając cechy osoby określanej inwektywą bydlę: 'o człowieku małowartościowym moralnie, bezmyślnym, godnym pogardy, podłym; bydlak'. Ponadto w polszczyźnie przenośnie obraźliwe określenie rozszerzyło swoje znaczenie, ponieważ bydło odnosi się również do ‘jakiejś grupy osób' [SJPDub, SJPDun]. Polski gad, którego odpowiednikami są ukraiński гад lub плазун, także jako zooinwektywa odnosi się do cech charakteru, określa się w ten sposób 'człowieka podłego, fałszywego, nikczemnego' [SJPSz, SJPDub], a także 'niegodziwca' [SJPDun]. Odpowiednik polskiego gada - гад ma podobne znaczenie: 'про огидну, підступну людину'. W ВТСБ, НТСЯ występuje też jako synonim wyrazu плазун. Jedynie dodatkowe przenośne znaczenie odnotował СУM, w którym podkreślono 'służalczość', 'uniżoność' osoby określanej jako плазун; 'той, хто по-рабському схиляєтсья перед ким-, чим-небудь, догоджає комусь, принижуєтья, вуслужується перед кимсь' .

${ }^{7}$ Dla przejrzystości wywodu pomijam szczegółowe adresy bibliograficzne. Wszystkie przykłady zostały wynotowane ze słowników stanowiących materiał źródłowy artykułu. Podaję źródło, jeżeli w danym haśle słownikowym są różnice w objaśnieniach i/lub definicja jest tylko w jednym lub dwóch źródłach.

${ }^{8} \mathrm{~W}$ analizie pomijam odniesienia ideologiczne, które rejestrują starsze słowniki. СУM podaje, że np. бидло to 'зневажлва назва поневолених трудящих, яку вживали експуататори, пани'; свиня to 'зневажлва назва представника нижчих верств населення (селян, міської бідоти та ін.), яку вживали представники привілейованих класів)'. 
Na podstawie przytoczonych powyżej hiperonimów można wysunąć bardziej ogólny wniosek. Mimo że Polacy i Ukraińcy należą do tego samego kręgu cywilizacyjnego, każdy zjęzyków odzwierciedla swój własny sposób postrzegania świata, przenośne znaczenia poszczególnych nazw zwierząt nie są identyczne, tylko niektóre z nich dadzą się sprowadzić do pewnego znaczenia wspólnego.

\section{Nazwy gatunkowe zwierząt w standardowej odmianie języka polskiego i ukraińskiego}

Negatywne konotacje mają zarówno hiperonimy, jak i nazwy gatunkowe zwierząt. Wśród nich dominują nazwy stworzeń żyjących blisko człowieka, baczniej obserwowanych i oswojonych, tzn. domowych (udomowionych), w drugiej kolejności znajdują się nazwy zwierząt hodowlanych, w znacznym stopniu oswojonych, ale żyjących w specjalnie dla nich przygotowanych pomieszczeniach, a na końcu dzikie, nieoswojone, z którymi człowiek ma rzadki i przypadkowy kontakt.

Obiektem językowej metaforyzacji stały się typowe - z punktu widzenia człowieka - zachowania i cechy zwierząt, np. 'kogoś głupiego' nazywa się m.in.: baranem, ostem, gęsia, koniem, owca, krowa, cielęciem (cielakiem), capem, jeleniem, 'kogoś naiwnego' - cielęciem (cielakiem), gęsia, kozłem, 'kogoś podłego' - klępa, bydlęciem, świnia , padalcem, wydra, 'kogoś podstępnego' - żmija, lisem, 'kogoś złego'-żmija, 'kogoś aktywnego seksualnie' - buhajem, 'kogoś upartego'-ostem, 'kogoś leniwego - krowa, 'kogoś niechlujnego' - klępa, świnia, flądrą, 'kogoś żyjącego cudzym kosztem' - trutniem, pijawka, 'kogoś dającego się wykorzystywać' - wołem. Z kolei 'хтось нерозумний' to баран, осел, корова, 'хтось нерозтропний' - хом'як, 'хтось покірний' - вівия, ягня, 'хтось хутий' - лис, в'юк, 'хтось злий' - змія, собака, 'хтось жорстокий' - n'явка, собака, 'хтось жадібний' - шакал. Zwraca się uwagę na właściwości fizyczne, np. 'kogoś grubego' nazywa się krowa, świnia, 'kogoś młodego wiekiem' - szczenięciem (szczeniakiem), kurczakiem, 'kogoś starego' - kobyta, capem, 'kogoś brudnego' - świnia, prosięciem (prosiakiem), capem, 'kogoś brzydkiego' - małpą, 'kogoś wysokiego' bocianem, zaś 'хтось незграбнй' to корова, хом'як, тюлень, 'хтось старий' йаn, 'хтось молодий' - теля, иуценя, 'хтось неповороткий' - хом'як, тюлень.

Za podstawę przeniesienia nazw zwierząt na człowieka posłużyły głównie cechy psychiczne i fizyczne oraz charakterystyczny sposób zachowania się. Niektóre z nich odnoszą się do kilku właściwości, dlatego też wyekscerpowane nazwy podzieliłam na trzy grupy, ograniczając materiał egzemplifikacyjny do minimum.

2.1. Wyrazy, których przenośne znaczenia częściowo się pokrywają w obu językach, np. baran/баран, cap/ųan, krowa/корова, kogut/niвень//когуm, chomik/ хом'як, kaтеleon/хамелеон, lis/лис, оsiot/осел//вілсюк, papuga/nanyгa, sukal 
сука, świnia/свиня, matpa/мавпа, pijawka/n'явка, żтіjа/змія//гадюка, truteńl трутень.

2.1.1. W języku polskim cap jest synonimem 'brodacza, głupca, bałwana'. Przenośnie capem nazywa się 'mężczyznę brodatego, zwłaszcza mającego brodę podobną do brody koźlej' oraz 'człowieka głupiego', a także 'mężczyznę, zwłaszcza starego i nieprzyzwoicie zachowującego się wobec kobiet' [SJPDub, SJPDun]. W języku ukraińskim zooinwektywa u̧an odnosi się również - jak w polszczyźnie - do cech fizycznych, oznaczając 'бродатого або старого чоловіка', ponadto wskazuje na ludzką wadę: 'чоловіка $з$ неприємним, фальшивим голосом'. W obu językach przenośne znaczenie częściowo się pokrywa: ujemne wartościowanie dotyczy wyglądu. W języku polskim rozszerzenie zakresu znaczeniowego związane jest ze sferą psychiczną i seksualną, zaś w - ukraińskim tylko z fizyczną.

2.1.2. W polszczyźnie kogut to słowo bliskoznaczne do 'zawadiaki', 'kobieciarza', 'babiarza' [SJPDun], oznacza 'mężczyznę uganiającego się za kobietami' (SJPSz, SJPDub), 'mającego duże potrzeby seksualne' [SJPDub], 'bardzo aktywnego seksualnie' (SJPDun) oraz 'człowieka czupurnego, zadziornego'. Z kolei півень ma węższy zakres znaczeniowy, częściowo pokrywający się z tym w polszczyźnie: 'задерикувата й запальна людина' i dotyczy jedynie cech psychicznych człowieka, ale w ukraińskim socjolekcie przestępczym łączy się ze sferą seksu i odnosi się do 'пасивного гомосексуаліста'. W przenośnym, potocznym znaczeniu funkcjonuje także zdrobnienie utworzone od півень, tj. півник: 'задерикувата й запальна, молода людина, дитина', które podają wszystkie słowniki ogólne języka ukraińskiego. Deminutiwum півник odnotowali H. Ułaszyn [Ułaszyn 1951: 52-53] oraz Л. Ставицька [Ставицька 2003: 205]. H. Ułaszyn zaznaczył, że w polskim języku złodziejskim wyraz piwnyk jest jednym z najstarszych zapożyczeń z ukraińskiego socjolektu przestępczego i oznacza tylko - 'koguta'.

2.2. Wyrazy, których przenośne znaczenia są całkowicie odmienne w obu językach, np. wydra/видра, larwa/лярва, szakal/шакал.

2.2.1. Obraźliwym, potocznym określeniem 'kobiety przebiegłej, kłótliwej, często też ubranej lub zachowującej się wyzywająco' jest zooinwektywa wydra odnotowana tylko przez SJPDub. W języku ukraińskim odpowiednikiem jest lekceważące, pogardliwe określenie 'про надмірно худорляву жінку' dotyczące jej wyglądu zewnętrznego. W socjolekcie wydra jest synonimem 'kobiety w ogóle', oznacza także 'prostytutkę starszą i kłótliwą'. Cecha 'kłótliwości', która jest wpisana w przenośne znaczenie wydry, łączy polszczyznę potoczną z socjolektem, wskazując na kierunek przeniesienia znaczenia: z socjolektu do polszczyzny potocznej. 
2.2.2. Pejoratywnym określeniem odzwierzęcym jest larwa. Obraźliwie i potocznie nazywa się tak 'kobietę niesympatyczną, złą, do której czuje się niechęć' (SJPDub). Wydaje się, że nazwanie kogoś лярва jest jednym z najbardziej deprecjonujących określeń w standardowej odmianie języka ukraińskiego. Лярва to 'гуляща жінка, шльондра, курва'. W polskim i ukraińskim socjolekcie przestępczym jednym z bliskoznacznych do wyrazu larwa jest 'prostytutka', tak samo jak w ukraińskim: лярва to 'повія'.

2.3. Wyrazy - wyzwiska, których obraźliwy, obelżywy, lekceważący, ironiczny itp. charakter wynika z kontekstu i może wskazywać na dowolną negatywną cechę przewidzianą przez nadawcę, np. ukr. бугай, буйвій, гніда, zaznaczając 'лайл. про людину' i/lub z podaniem szerszego kontekstu, pol. pies 'o ludziach - używane jako wyzwisko' (SJPSz) lub 'pogardliwie ze złością o człowieku, najczęściej w funkcji wyzwiska' (SJPDun).

\section{Nazwy gatunkowe zwierząt w substandardowej odmianie języka polskiego i ukraińskiego}

Wszystkie nazwy dotyczą bezpośrednio lub pośrednio środowiska przestępczego (złodziejskiego, dewiacyjnego). Ze względu na znaczenie tworzą one kategorie: 1) nazwy złodziei, zależne od specjalności, przedmiotu, miejsca, sposobu i metod kradzieży, np. wróbel, indyk, kot, szczeniak - 'złodziej kradnący rzeczy małej wartości', миша - 'кишенковий злодій, який здійснює крадіжки в метро'; 2) nazwy przestępców (oszustów, przemytników itp.) oraz ich pomocników, np. koń, wilk, rekin - 'przestępca dewizowy', кнур - 'кооператор'; 3) nazwy określające wrogów przestępców, np. wrona - 'nazwa ławnika', вівия - 'свідок'; 4) nazwy osób związanych $\mathrm{z}$ wymiarem sprawiedliwości, z przebywaniem $\mathrm{w}$ areszcie ( $\mathrm{w}$ więzieniu, zakładzie karnym itp.), np. mrówka - 'wychowawca', шакал - 'засуджений, який грабує співкамерніків'; 5) nazwy osób poszkodowanych przez przestępców, np. baran, koń - 'ofiara kradzieży', вівия - 'жертва злочину'; 6) nazwy osób nadużywających alkoholu, np. baran - 'pijak', заєць - 'п’яний'; 7) nazwy przedstawicieli zawodów niezwiązanych bezpośrednio ze środowiskiem przestępczym, np. wrona - 'zakonnica', вовк - 'шофер тахi'; 8) nazwy osób łączonych ze sferą seksu, np. kukutka - 'prostytutka', кобра - 'жінка, яка бере в рота статевий орган когання'; 9) nazwy, odnoszące się do właściwości fizycznych i psychicznych człowieka, np. śledź - 'szczupły człowiek', ведмідь - 'здоровий чоловік', dzięciot - 'człowiek niewinny, naiwny, dający się oszukać', дятел - 'дурень'; 10) nazwy osób wskazujące stopień pokrewieństwa (relacji rodzinnych), np. rekin‘syn, dziecko', риба - ‘жінка'. 
W socjolektach definicje są bardzo rozbudowane. Nazwy odzwierzęce mają po kilka, a w polskim socjolekcie przestępczym nawet po kilkanaście znaczeń, np. pająk (27), pies (18), koń (17), kot (13), nie wszystkie jednak z nich odnoszą się do ludzi, ale wszystkie służą utajnieniu informacji, uniemożliwieniu osobom niewtajemniczonym łatwe odczytanie sensu wypowiedzi. Polskie nazwy i ich ukraińskie odpowiedniki podzieliłam na dwie grupy.

3.1. Nazwy, których przenośne znaczenie (znaczenia) częściowo się pokrywa (pokrywają), np. kogut/nівень, larwa/лярва, mysz/миша, rekin/акула, szakal/ шакал, szczепiak/иуцик, kobyta/кобила, kосіса/кішка, kot/кim, koziot/козел, jeleńl олень, тисhа/муха, bаżant/фазан. Niektóre z tych przenośnych znaczeń bardziej się upowszechniły, występują nie tylko w środowisku przestępców (złodziei, oszustów), ale także przeszły m.in. do polszczyzny potocznej (np. jeleń, kocica, rekin).

3.1.1. W ukraińskiego оленя і polskiego jelenia wpisana jest cecha charakteru, tj. 'naiwność'. W socjolekcie przestępczym jeleń użyty w stosunku do człowieka oznacza m.in. '1. obcego, niezłodzieja, ofiarę przestępcy, 2. człowieka naiwnego, głupca, osobę stawiającą wódkę, przygodnego znajomego, znajomego fundującego libację w knajpie, 3. klienta prostytutki, 4. mężczyznę, 5. skazanego nienależącego do nieformalnej grupy grypsującej', z kolei олень to 'наївна людина'. Nazwa ta funkcjonuje także w polszczyźnie potocznej jako synonim 'frajera'. W przenośnym znaczeniu, które odnotowały wszystkie słowniki ogólne, pogardliwie mówi się w taki sposób 'o naiwnym, łatwo dającym się oszukać i wykorzystać człowieku'.

3.1.2. Wspólnymi cechami przeniesienia nazwy zwierzęcia koziot oraz jego odpowiednika козел są właściwości dotyczące zwierzchnictwa, władzy oraz sfery seksu. W obu socjolektach przestępczych nazwy te mają kilka znaczeń, ale w obu aktywizują się cechy 'homoseksulaność', 'władza'. Koziol to m.in. '1. człowiek pijany, pijak, 2. fundujący wódkę, 3. ofiara przestępstwa, 4. komendant jednostki milicyjnej, 5. homoseksualista', zaś козел- '1. зрадник, донощик, 2. гомосексуаліст пасивний, 3. представник органів правопорядку’.

3.2. Nazwy, których przenośne znaczenie (znaczenia) jest (są) całkowicie odmienne w obu socjolektach, np. byczek/бичок, byk/бик, koń/кiнь, zają/заєų, fokal тюлень, сzајkа/чайка, dzięcioł/дяатль, со mоże wynikać z hermetyczności obu środowisk, w którym funkcjonują, a także celów, jakim służą tzn. głównie kodowaniu znaczeń (tajności), wewnątrzgrupowej, szybszej i precyzyjniejszej wymianie informacji, integracji swojego środowiska.

3.2.1. Nazwa $b y k$, której prymarne znaczenie wiązało się z nazwą zwierzęcia hodowlanego, w żargonie przestępczym oznacza m.in. 'ofiarę kradzieży kieszon- 
kowej', z kolei бик to 'фізично сильний чоловік'. Podstawą przeniesienia nazwy zwierzęcia бик na człowieka była cecha związana z siłą, tężyzną fizyczną. Cechę tę wykorzystuje się również w polszczyźnie potocznej pogardliwie bykiem określa się 'dużego, tęgiego, silnego mężczyznę (zwłaszcza niechętnego do pracy)', ale w socjolekcie przestępczym nastąpiło odwrócenie znaczenia: 'siłę, moc' przeciwstawiono 'brakowi siły, niemocy - ofiarę'.

3.2.2. Różne znaczenia ma zając oraz odpowiednik заєu̧ь. W socjolekcie заєu̧ь to 'п'яна людина', z kolei zajacem nazywa się '1. pomocnika złodzieja kieszonkowego, 2. przekraczającego nielegalnie granicę, przemytnika, 3. żołnierza, 4. pracownika operacyjnego milicji’.

\section{Zakończenie}

Zarówno język polski, jak i ukraiński w swych odmianach standardowej i substandardowej korzystają obficie ze słownictwa obejmującego nazwy zwierząt. Użyte w stosunku do człowieka funkcjonują w mniejszym lub większym stopniu jako określenia obelżywe, wulgarne, wyrażające lekceważenie, ironię czy pogardę. Rosnąca liczba zooinwektyw w języku polskim i ukraińskim świadczy o coraz częstszym używaniu nazw zwierząt (hiperonimów i nazw gatunkowych) jako środka do poniżania, ośmieszania człowieka lub grupy ludzi. W substandardowych odmianach obu języków prócz funkcji ekspresyjnej nazwy zwierząt wykorzystywane są do intencjonalnego kodowania informacji. W obydwu odmianach i obu językach z jednej strony poszerza się semantyka wyrazów, których prymarne znaczenie odnosiło się do nazwy zwierzęcia domowego i hodowlanego, a z drugiej - powiększa się liczba używanych nazw zwierząt dzikich. Niektóre z zooinwektyw odnosiły się do kilku cech. Obiektem językowej metaforyzacji były m.in. właściwości psychiczne, fizyczne oraz sposób zachowania się zwierząt, pogrupowane w wyrazy, których przenośne znaczenie (znaczenia) się pokrywają oraz takie, których przenośne znaczenia są całkowicie odmienne w obu językach i odmianach.

\section{Wykaz skrótów}

SJPSz - Stownik języka polskiego, red. M. Szymczak, Warszawa: PWN, 1996, t. I-III. SJPDub - Uniwersalny stownik języka polskiego, red. S. Dubisz, Warszawa: PWN, t. I-IV. SJPDun - Język polski. Wspótczesny stownik języka polskiego, red. B. Dunaj, Warszawa: Wydawnictwo Langenscheidt, 2007, t. I-II.

SGD - Stępniak K., Stownik gwar środowisk dewiacyjnych, Warszawa: Departament Szkolenia

i Doskonalenia Zawodowego MSW, 1986. 
СУМ - Словник української мови: в 11 тт., ред. І.К. Білодіда, Київ: Наукова думка, 19701980.

ВТСБ - Великий тлумачний словник сучасної украӥнської мови, ред. В.Т. Бусел, Київ: ВТФ Перун, 2001.

НТС - Новий тлумачний словник сучасної украӥнської мови: в трьох томах, ред. В. Яременка, О. Сліпушко.

СЖ3 - oraz Словник жаргону злчиниів, О.І. Поповченко, Київ: ТОВ Оберіг, 1996.

\section{Bibliografia}

Grabias S., Język w zachowaniach społecznych, Lublin: Wydawnictwo Uniwersytetu Marii Curie Skłodowskiej, 1997.

Kamińska-Szmak I., Agresja językowa w życiu publicznym. Leksykon inwektyw politycznych 1918-2000, Wrocław: Wydawnictwo Uniwersytetu Wrocławskiego, 2007.

Kołodziejek E., Językowe środki zwalczania przeciwnika, czyli o inwektywach we współczesnych tekstach politycznych, [w:] „Język a Kultura”, tom 11: Język polityki a wspótczesna kultura polityczna, red. J. Anusiewicz, B. Siciński, Wrocław: Wydawnictwo Uniwersytetu Wrocławskiego, 1994, s. 69-74.

Peisert M., Formy i funkcje agresji werbalnej. Próba typologii, Wrocław: Wydawnictwo Uniwersytetu Wrocławskiego.

Sarnowski M., Przestrzeń komunikacji negatywnej w języku polskim i rosyjskim. Kłótnia jako specyficzna forma komunikacji werbalnej, Wrocław: Wydawnictwo Uniwersytetu Wrocławskiego, 1999.

Skawiński J., Nazwy zwierząt jako inwektywy w języku polskim i niemieckim, [w:] Wyraz i zdanie w językach słowiańskich 3. Opis, konfrontacja, przekład, I. Łuczków, J. Sokołowski, Wrocław: Wydawnictwo Uniwersytetu Wrocławskiego, 2002, s. 257-268.

Ułaszyn H., Język złodziejski, Łódź: Łódzkie Towarzystwo Naukowe, 1951.

Ставицька Л., Короткий словник жаргонної лексики української мови, Київ: Критика 2003. Ставицька Л., Український жаргон. Словник, Київ: Критика 2005.

\section{References}

Grabias S., Język w zachowaniach społecznych [Language in Community Preservation], Lublin: Wydawnictwo Uniwersytetu Marii Curie Skłodowskiej, 1997.

Kamińska-Szmak I., Agresja językowa w życiu publicznym. Leksykon inwektyw politycznych 1918-2000 [Language Aggression in Public Life. Lexicon of Political Infectious Diseases 1918-2000], Wrocław: Wydawnictwo Uniwersytetu Wrocławskiego, 2007.

Kołodziejek E., Językowe środki zwalczania przeciwnika, czyli o inwektywach we współczesnych tekstach politycznych [Linguistic means of defeating of the enemy, or reading about injecting in common political texts], [w:] „Język a Kultura”, tom 11: Język polityki a współczesna 
kultura polityczna, red. J. Anusiewicz, B. Siciński ["Language and Culture”, volume 11: Language of politics and political political education, ed. J. Anusiewicz, B. Siciński,], Wrocław: Wydawnictwo Uniwersytetu Wrocławskiego, 1994, s. 69-74.

Peisert M., Formy i funkcje agresji werbalnej. Próba typologii [Forms and functions of verbal aggression. Attempt of typology], Wrocław: Wydawnictwo Uniwersytetu Wrocławskiego. Sarnowski M., Przestrzeń komunikacji negatywnej w języku polskim i rosyjskim. Kłótnia jako specyficzna forma komunikacji werbalnej [Space of negative communication in Polish and Russian. Quarrel as a very specific form of verbal communication], Wrocław: Wydawnictwo Uniwersytetu Wrocławskiego, 1999.

Skawiński J., Nazwy zwierzat jako inwektywy w języku polskim i niemieckim [Names of animals as invectives in Polish and German], [w:] Wyraz i zdanie w językach słowiańskich 3. Opis, konfrontacja, przektad, red. I. Łuczków, J. Sokołowski [Word and sentence in Slavic languages 3. Description, confrontation, translation, ed. I. Łuczków, J. Sokołowski], Wrocław: Wydawnictwo Uniwersytetu Wrocławskiego, 2002, s. 257-268.

Ułaszyn H., Język złodziejski [The Thieves Language], Łódź: Łódzkie Towarzystwo Naukowe, 1951.

Stavytska L., Korotkyi slovnyk leksyky ukrayins'koyi movy [Short Dictionary of Jargon Vocabulary of the Ukrainian Language], Kyiv: Krytyka, 2003.

Stavytska L., Ukrains 'kyi zhargon. Slovnyk [Ukrainian Slang. Dictionary], Kyiv: Krytyka, 2005. 